\title{
The Political Marketing Strategy of Mayor and Deputy Mayor of Malang City (A Phenomenological Study on the Success of Mohammad Anton and Sutiaji (Mas) in Winning the Mayor Office)
}

\section{Moh. Erfan Arif}

Management Department, Faculty of Economics and Business, University of Brawijaya

\section{Abstract}

The objectives of this study are to reveal the political marketing strategy carried out by the winning team of Moch. Anton - Sutiaji, Mayor - Deputy Mayor candidate of 2013, and to understand their form of campaign. This study uses qualitative method with phenomenological approach. The findings of the study show that the winning team

Corresponding Author:

Moh. Erfan Arif

erfan_arif99@yahoo.com

Received: 29 August 2018

Accepted: 18 September 2018

Published: 11 November 2018

Publishing services provided by Knowledge

(c) Moh. Erfan Arif. This article is distributed under the terms of the Creative Commons

Attribution License, which permits unrestricted use and redistribution provided that the original author and source are credited.

Selection and Peer-review under the responsibility of the ICOI-2018 Conference Committee.

\section{G OPEN ACCESS} of the aforementioned pair understand the political marketing environment well. By knowing the need of voter market (society), utilizing the internal force of supporting organization, using the support of big capital (fund), relying on the managerial skill of the candidate, making a huge social investment (generosity), and arranging campaign activities relevant to the need of voter market in the form of holding free religious trip and giving door prize as the stimulant, this pair formed an accurate strategy in winning the office in 2013.

Keywords: political marketing strategy, environment, campaign form

\section{Introduction}

In direct vote, introduction of regional leader candidates to the society through political campaign was used as the main strategy to attract the attention and to gain vote from the targeted legible subjects (Yustian, 2008). Astuti (2008) asserted that marketing concept can give a better result in the process of political competition, as the election of mayor of Malang in 2008. To win a political competition, candidates need to employ a marketing approach as means of communication between the candidate and the voter market. It is true that marketing approach cannot guarantee a victory in political area, but it can help build a concept that will help parties, candidates, and political programs to be offered, as to offer commercial products (Cangara, 2009). Marlan (2003) also asserted that the election in Canada needed to apply political marketing concept without adopting the political marketing style of the USA. 
The competition toward mayor office of Malang City in Indonesia in 2013 involved six pairs of candidate. The following is the name of the candidates and the percentage of votes they gained: (1) Dwi Cahyono-M Nuruddin (DWI-UDIN) 5.83\%, (2) Sri Rahayu-Priyatmoko (SR-MK) 22.25\%, (3) Heri Pudji Utami-Sofyan Edy (DADI) 18.17\%, (4) Ahmad Mujais-Yunar Mulya (RAJA) 2.51\%, (5) Agus Dono-Arif HS (DOA) 3.91\%, (6) Moch. Anton-Sutiaji (MAS) 47.33\%. The competition was won by Moch. Anton-Sutiaji (referred as MAS throughout this article) with a significant vote of $47.33 \%$, or 179.675 votes in one round of election. This pair was supported by the smallest coalition of parties (7 representatives on the legislative) comprised of 5 legislatures of PKB and 2 legislatures of Gerindra.

Analyzed from the support of the political parties, city and ethnicity, and the duration of their existence in politics, Moch. Anton-Sutiaji (MAS) were predicted to be difficult to win the election. However, the result of the voting showed that this pair gained the most vote with a significant gap compared to the pairs consisting of Malang-born and Javanese-origin people and to the pairs of who have been in politics for a longer period. This is the reason why this phenomenon is an interesting topic to discuss, particularly from the perspective of political marketing strategy.

Based on the aforementioned description, the focus of this study is identifying the ways of the winning team of the winning pair (MAS) understand the environmental condition of marketing politics in Malang as the basis for their policy making in their campaign. Further, as a response to the understanding, the author also emphasizes the identification of campaign forms carried out by MAS.

\section{Literature Review}

Political marketing is defined as a process of analyzing, planning, and implementing marketing concepts in elections designed to create, establish, and maintain mutual trading relationship between political parties and voters to achieve a goal (O'Cass, 1996:40). Political marketing as a discipline has gradually found its own framework. The framework adapts the core literature of marketing, which was built on the basis of prediction and perspective of political science (Lock and Harris, 1996).

Firmanzah (2008) stated that the use of commercial marketing in politics was known as political marketing. It can be said that the higher the competition level in the political world, the more strategies are needed to win the competition. According to Susanto (2011), the process of political marketing includes four activities: holding market/voter researches, developing strategies, setting programs, and evaluating and rebuilding 
models. Potincu (2009) implied political research based on voter's political attitude, party image, politician, and election process.

Buttler and Collins (2001) stated that, as the time goes by, there was a frequent increase on the movement of voters' volatility. Of course, this situation illustrates that the tendency of voters toward certain political parties is unpredictable, so the winning candidate is the candidate who is perceived by voters offering something different and better. It implies the importance of marketing concept application in politics (Firmanzah, 2008).

Following the definition of traditional marketing, political marketing is more precisely described as a set of activities, processes, or political institutions used by political organizations, candidates, and individuals to create, communicate, deliver, and exchange promises of value with voter-consumers, political party stakeholders, and society at large (Hughes \& Dann, 2009). Political organizations have myriad of goals and, generally, seek effective strategies to compete in democratic contests (Osuagwu, 2008).

The usage of marketing's 4 Ps in political world makes political marketing becomes more than just an advertising matter; it becomes more comprehensive than that. Political marketing deals with ways of a political institution formulate political products, arrange publication programs of the campaign and political campaign, make segmentation strategy to fulfill the needs of the society, and also fix the price of a political product (Firmanzah, 2008)

\subsection{The marketing mix of politics}

\section{Methods}

This study uses phenomenological qualitative method. To reveal the problems, this study involves four key informants, who were involved directly in the process of strategic arrangement for the winning of MAS in mayor-deputy mayor election in Malang in 2013. This phenomenological data analysis tries to explain or reveal the meaning or experience phenomena which were based on the consciousness of several individuals. Those individuals were assumed proper informants as needed by this study.

\section{Results and Discussion}




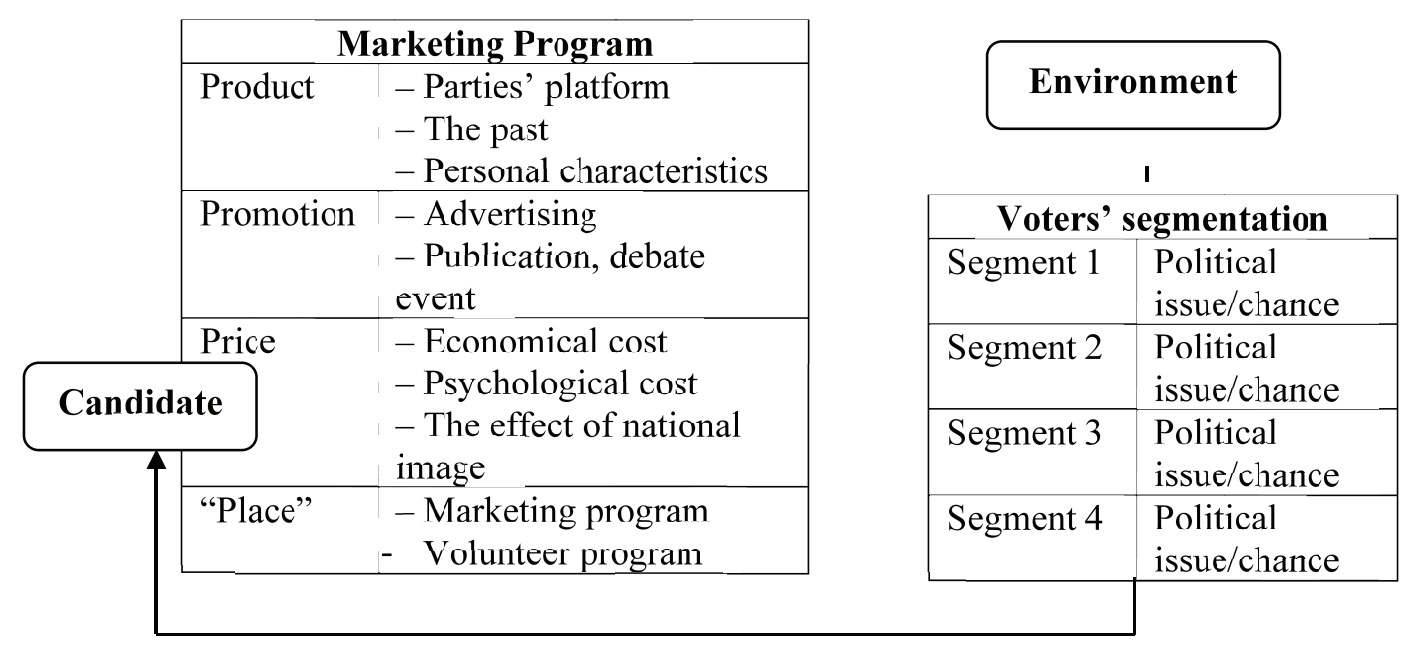

Source: Nifenengger (1989) in Firmanzah (2008).

\subsection{Theme of study}

After data reduction, which was preceded by determining the key information and addressing its meaning, several themes were obtained:

1. Supporting organization

2. Huge capital

3. Managerial skill

4. Social investment

5. Societal understanding

6. Religious trip, door prize

\subsection{Minor proposition}

From the aforementioned themes, there are six minor propositions that appear:

1. Minor proposition 1

The use of internal resources, such as supporting organizations, is a strategic move to win MAS

2. Minor proposition 2

The capital at hand is an important strategy in the winning effort of MAS. 


\section{Minor proposition 3}

The inherent managerial skill plays an important role in the winning of MAS.

4. Minor proposition 4

Social investment (generous conduct) done by Moch. Anton has a great effect on the victory of MAS.

5. Minor proposition 5

Understanding societal needs (voter market) is an accurate strategy for MAS to reach victory.

\section{Minor proposition 6}

Religious trips (ziarah wali) and stimulants of door prize is an effective strategy in the victory of MAS

\subsection{Analysis on minor Proposition 1}

Nahdlatul 'Ulama (NU) is one of the biggest social organizations in Malang. It has a huge number of members covering all groups of age as reflected in its autonomous institutions, such as teenagers, pupils, university students, adults, and elders. Each autonomous institution provides different sub organization for males and females. To mobilize the huge mass of $\mathrm{NU}$ members, one needs to involve the Kiyais (Kiyai is a scholar of Islamic religion and/or Islamic traditional dormitory school, respected by people for their knowledge and influence). This is also an important thing to do, since, despite of its urban nature, Malang is a paternalistic city.

Besides NU, there was another organizations that supported the winning process of MAS. Gerindra, a political party, and its wing organization were also involved in the winning process. Gerindra has several wing organizations that empower women and youth and provide health services for the society. A group in the society targeted by MAS was Chinese. Generally, citizens of Malang from Chinese ethnicity are Christians. It was not something difficult to influence them because the mayor candidate, Moch. Anton is also from Chinese ethnicity. Previous studies showed that the existence of social organization or social communicational knots gave a significant support in winning certain regional leaders. The support of social communicational knots (organizations) was able to win certain regional leader and to reduce the campaign cost of Kelik Sumoharjo in the regional election of Purworejo in 2005 (Prihatini, 2011). 


\subsection{Analysis of minor Proposition 2}

Parallel to the concept of price in political marketing mix, the expenses paid by regional leader candidates are used for normal campaign needs, including administrative needs, payment for the winning team, and payment of voting witnesses. Expenses that exceed the limit of normality and is assumed as money politic are not appropriate for the concept of political marketing mix.

As a part of political marketing mix components, price is also a determining factor for the success in regional leader election competition. Winning efforts in Indonesian politics was generally included in high-cost category. In other words, it needs a huge cost to become a regional leader. Capital is an important factor that needs to be considered by candidates of regional leader since the market or the society in Malang, and generally in Indonesia, is pragmatic in using their vote. Most voters will vote sides that give them certain benefits.

The strategy of big capital in the political campaign of regional leaders is widely used in Indonesia. This is done to influence the political choice of the society to gain majority votes. This capital strategy is supported by the study of Pantouw (2012), which stated that the availability of money as the capital for winning determines the victory of a candidate.

However, in the politics of regional leader election in Malang, the concept of price is applied reversely. Voters, which should be the consumers, turned into the producers. The candidates of regional leader, which should be the producers, turned into consumers. Voters became the producers that sell his vote to the candidates for certain amount of benefit such money, goods, or services.

\subsection{Analysis on minor Proportion 3}

Based the statements of the informants, it can be concluded that the victory of Moch. Anton in mayor election in Malang is based on the consideration of his generosity and social investment. However, this does not mean that his capacity and ability in managing the government was a peripheral factor. The managerial skill of Moch. Anton can be seen in his success in managing his companies; they are PT. Maju Jaya Makmur Sentosa, PT. Candra Wijaya Sakti, and CV. Surya Kencana. Those companies make a big gain and contribute to the asset owned by Moch. Anton. Besides his experience in managing those companies, he also has an experience of becoming the treasurer of 
NU of Malang for more than five years, not to mention that he was the chairperson of PITI (Union of Indonesian Moslem Chinese) of Malang.

During his career, he did not have the experience of sitting in governmental office. To overcome this weakness, he chose Sutiaji as his deputy for the election. Before his candidacy, Sutiaji was the member of DPRD (city legislative) of Malang from 20092014 and the chairperson of PKB faction, in which he has a sound track record. This was proven by his numerous activities as the representative of DPRD to work with the government of the city and also with educational institutions. From the aforementioned description, it can be concluded that the skill and competence of a candidate affect the voter market in determining who will sit in the office. This is in accordance with the research of Todorov et al., (2005) which concluded that competence owned by a candidate affects people's vote in an election.

\subsection{Analysis on minor Proposition 4}

Moch. Anton is a mualaf (a person newly converted to Muslim), famous in Malang for his generosity. As a successful businessperson with big assets, he shares a lot with poor people. For more than six years he has been holding istighotsah kubro (Islamic prayer) every Friday legi (legi is one of the days in Javanese calendar system). The activity attracts thousands of people from Malang City, Malang Regency, and Batu City. The participating people also receive benefit in a form of daily-need products. This can build a strong positioning in voters' mind.

He donates more than IDR 400 million every month for the orphans. This activity has been done since long before his candidacy. Further, he sends more than 100 people every year for umroh to Saudi Arabia. He also often gives social donation to build mosques and to social institutions. Another activity he sponsored is ziarah wali (a trip to visit the tomb of people who spread Islam for the first time in Java) for groups of people, where he covers all the expenses.

As in determining products to be sold for commercial purpose, choosing people for mayor as a political product also needs a detailed consideration. According to O'Shaughnessy (2001), political marketing is not a concept of selling political parties or candidates to voters. Instead, it is on how political parties or candidates offer programs that meet the needs of the society. It is clear, then, that the primary thing to sell is the working program and actual ideas relevant to the need of the society. Moch. Anton was elected mayor of Malang not in a short journey. He has been holding various social investments with political value since six to seven years ago. It means that, to 
become a regional leader a candidate needs socio-political investment processes to set a strong positioning in the eye of the voters (Mage, 2013).

\subsection{Analysis on minor Proposition 5}

In understanding political marketing environment, we need to know the internal and external condition of MAS, which is the understanding on the need of the society. From the internal point of view, MAS, supporting parties, and NU are components strengthening each other for the sake of the candidate. Moch. Anton had a positive image, whom people believe a generous and capitally ready person. Sutiaji, with his organizational experience in NU and PKB, was the perfect wing man for Moch. Anton to embrace people from NU. From the perspective of supporting parties, PKB and Gerindra are parties with good images.

From the external point of view, understanding the need of the society (voter market) becomes the determining strategy for mayor candidates to gain most vote. People who live in a same city still have a different demographic, such as in education, income, origin, religion, and culture. Accordingly, their need to be developed in the campaign programs must be identified.

Therefore, understanding the strength and understanding the characteristics of voter market are important in achieving political victory. Understanding on voters' characteristics guides candidates or political parties in building an effective communicational relationship (Smith and Hirst, 2001:1060). Hence, what is going to be given during the campaign period will be accepted well by the voter market.

\subsection{Analysis on minor Proposition 6}

According to the winning team's perception, the voting behavior of Malang people is mostly influenced by what is given by the candidates, which means that most voters vote for candidates who are willing to give benefits (money, goods, or service). Referring to the behavior of voter market, MAS's winning team provided interesting campaign programs which were not used by other candidates, such as holding religious trip and giving stimulants in forms of valuable and interesting gifts during open campaigns.

Providing religious trip is something unique in marketing or campaign. This was done only by MAS. Offering trips to five places by bus, this program was greatly responded by the society. During the campaign period, MAS handled 1600 trips with the cost of 
IDR 6.4 billion (at the cost of IDR 4 million for each trip). Taking 50 people per trip, the program accommodated 80.000 participants.

The other form of campaign assumed effective in influencing the voter market is distributing valuable gifts during the open campaign. The gifts being offered were household utensils, bicycle, refrigerator, motorcycle, and accommodation for umroh. Beside those form of campaigns, MAS also did campaign like other candidates such as through billboards, banners, flyers, pamphlets, newspapers, televisions, etc.

Accuracy in determining campaign form will determine the effectiveness of the result, with regard to the aimed market segments and targets. A study carried out by Wulandari (2013) stated that, in arranging political campaign program, the profile of the voter market should be observed thoroughly. Form of campaign like religious trip is suitable for market of Nahdliyin (NU affiliates), while gifts are a favorable form of campaign for most Malang people.

\subsection{Analysis on major Proposition}

From the aforementioned minor propositions, a major proposition can be extracted, that is empowering internal strengths such as supporting organizations, huge capital, managerial skill, social investment, understanding on society's need, and proper arrangement of campaign forms following the interest of voter market were accurate strategies in the victory of MAS in mayor election of Malang 2013.

From the discussion of aforementioned minor propositions, it can be seen that winning strategy by involving and empowering internal strengths of supporting organizations was a precise move. Supporting organizations like Nahdlatul 'Ulamo (NU) and its autonomous organizations and Gerindra's wing organizations were involved in the winning process.

As a political product, candidates of regional leader, on one side, should accentuate factors of capability (quality) in running governmental organizations, although, on the other side, should consider factors of popularity and electability. Considering the track records of MAS, both (Moch. Anton and Sutiaji) have a deep skill in carrying out their mandate as a mayor and deputy mayor. Even though their experience in the government was not as much as other candidates, their potentials were assumed to be sufficient to run the city's governmental organizations.

Understanding the environment of political market by identifying the voter market is a must for candidates. The existing internal condition seemed to be beneficial for MAS. The solidity of the winning team that was able to embrace supporting organizations 
had become a significantly contributive force. Huge capital and positive image of this pair familiar to public as a generous person had created a positive positioning in the society.

After understanding the condition and the need of the voter market (political marketing environment) of Malang, the next step was responding to it using suitable campaign forms. Generally, the form of campaign taken by MAS was not very different with other candidates, except the two forms of communication with their constituents: religious trip and stimulants in form of door prizes during open campaign period. This form of campaign was assumed to be an effective strategy in affecting voter market.

Based on the aforementioned descriptions, it can be inferred that politicians especially in Malang should combine several things to obtain most vote. Hence, from the discussion on the aforementioned propositions, it can be concluded that understanding political marketing environment by identifying the need of voter market (society), optimizing the force of supporting organizations, capital support, managerial skill of the candidate, level of social investment (generosity), religious form of campaign, and stimulants of gifts in open campaign period was the accurate strategy to win the mayor election of Malang in 2013.

\section{Conclusion}

1. Understanding political marketing environment by identifying the need of voter market, optimizing the force of supporting organizations, support of capital, managerial skill of the candidate, level of social investment (generosity), religious form of campaign and stimulants of attractive gifts were the accurate strategy to win the mayor election of Malang in 2013.

2. Forms of campaign effective for influencing voter market of Malang were forms suitable for public, they were: inviting people eligible for voting to join a religious trip to wali lima (five of nine Islamic scholars who spread Islam in Java) in East Java, and giving stimulants in forms of attractive prizes such as household utensils, bicycle, refrigerator, motorcycle, and accommodation for umroh to invite people to attend the open campaign until it is over. Beside those forms, the team also did a similar way of campaign to the other candidates, such as through billboards, banners, posters, and other printed media. 


\section{Acknowledgement}

The researcher presents his sincere appreciation to Widya Farid Iskandar (Gerindra Party), Moch. Syafik (PKB Party), M. Nur Wahyudi (Chief of MAS Winning Team), Sutiaji (Deputy Mayor Candidate) as the key informants of this research. He is also thankful to Brawijaya University and to his little family for their support.

\section{References}

[1] Astuti, W. (2008). Peranan Pemasaran Politik Kandidat Dalam Meyakinkan Pemilih Pada Pilkada Koto Malang. Makassar: National Conference on Management Research.

[2] Butler, P. and Collins, N. (2001). Payment on delivery: Recognising constituency service as political marketing. European Journal of Marketing, vol. 35, no. 910, pp. 1026-1037.

[3] Cangara, H. (2009). Komunikasi Politik: Konsep, Teori dan Strategi. Jakarta: Rajawali Pers.

[4] Firmanzah. (2008). Marketing Politik, Antara Pemahaman dan Realitas. Jakarta: Yayasan Obor Indonesia.

[5] Hughes, A. and Dann, S. (2009). Political marketing and stakeholder engagement. Marketing Theory, vol. 9, no. 2, pp. 243-256.

[6] Lock, A. and Harris, P. (1996). Political marketing vive jla difference. European Political Marketing, vol. 30, no. 10/11, pp. 21-31.

[7] Mage, I. R. (2013). Berpolitik Dengan Biaya Murah. Jakarta: Sipil Institut.

[8] Marland, A. (2003). Political marketing in modern Canadian federal elections. Paper for Presentation at the Canadian Political Science Association Conference 2003: Dalhousie University.

[9] O'Cass, A. (1996). Political marketing and the marketing concept. Europeon Journal of Marketing, vol. 30, no. 10/11; ABI/INFORM pp. 37-53.

[10] O'Shaughnessy, N. (2001). The marketing of political marketing. European Journal of Marketing.

[11] Osuagwu, L. (2008). Political marketing: Conceptualisation, dimension, and research agenda. Marketing Intelligent and Planning, vol. 26, no. 7. Emerald Group.

[12] Pantouw and Ignasia, M. S. (2012). Modalitas dalam Kontestasi Politik (Studi Modalitas dalam Kemenangan Pasangan Hanny Sondakh dan Maximiliaan Lomban 
pada Pemilukada di Koto Bitung Sulawesi Utara 2010). Thesis: Universitas Diponegoro Semarang.

[13] Potincu, R. C. (2009). Features of the socio-political marketing. Bulletin of the Transilvania University of Brasov, vol. 2, no. 51.

[14] Prihatini, E. (June 2011). Penggunaan Simpul-Simpul Komunikasi Sosial sebagai Strategi Kampanye. Jurnal Ilmu Komunikasi, vol. 8, no. 1, pp. 81-102. Yogyakarta: Universitas Atmajaya.

[15] Smith, G. and Hirst, A. (2001). Strategic political segmentation: A new approach for a new era of political marketing. European Journal of Marketing, vol. 35, pp. 1058-1073.

[16] Stoner, J. A. F. and Freeman, R. E. (1992). Manajemen. Jakarta: Intermedia.

[17] Todorrov, A., Mandizodza, A. N., Gorren, A., et al. (2005). Inferences of competence from face predict election outcomes. Science, vol. 308.

[18] Wulandari, R. (2013). Strategi Kampanye Politik Koalisi Partai Pengusung AfiMukmin dalam Pemilihan Gubernur Tahun 2013. ejournal Ilmu Komunikasi Fisip Unmul.

[19] Yustian, Y. (2008). Strategi Kampanye Politik Calon Incumbent dan Pendatang Baru dalam Pemilihan Kepala Daerah (Studi Kasus: Tim Kampanye Pasangan Danny Setiawan-Iwan Sulanjana dan Ahmad Heryawan-Dede Yusuf Di Koto Bogor, Jawo Barat). Skripsi Program Studi Komunikasi dan Pengembangan Masyarakat Fakultas Pertanian. Bogor: Institut Pertanian Bogor. 